\title{
Some Aspects of the Economic Nature of Contracts as they Relate to Forest Land Tenure in Alberta
}

\author{
Michael Carroll \\ University of Alberta
}

\section{Introduction}

\section{a) Conceptual Framework and Objective}

The disposal of public timber resources has been the subject of much critical review. Aspects which have captured the attention of economists and foresters alike, include the impact of timber utilisation on other forest land resources, and the means by which net social benefits may be maximised.

A common form of timber disposal to the private sector has been the exchange of certain property rights through the medium of contracts. A continuum of property rights could be postulated from the maximum bundle to zero rights. A Province possesses the maximum bundle of rights, defined as outright property ownership and constrained by the legal institutions of society. Rights to use forest land for timber management may be traded to private sector companies in exchange for financial compensation. External costs and benefits will be included in the Provincial evaluation of the adequacy of financial compensation. Ideally, rights to which the Province attributes a higher value of net social benefit than the company would be prepared to pay, are not exchanged. For example, the right to sole occupancy is usually not exchanged since public access for hunters or other recreationists is given an implicit value by the Province which exceeds the amount the company would be willing to pay, particularly in view of the company's probable inability to operate a recreation facility of sufficient profitability.

The criterion which a Province should use in these circumstances is the present value of net social benefits. This is the discounted benefits minus costs, including externalities, and will be maximised when all property rights for which the firm is able to pay at least the social opportunity cost have been exchanged.

The purpose of this paper is to describe the system of contracts through which timber disposal is carried out in Alberta. The rights which are exchanged are identified and whenever possible, the probable effect of this exchange point on the present value of net social benefits is discussed. The lack of information on the technical efficiency of various management systems and of a means to measure the output of non-timber forest land resources inevitably limits the analysis.

A company negotiating for rights to be exchanged in a contract will require the timber price and extraction and processing costs to be at a level which permits maximum attainable profit- ability. The Province on the other hand should require the total of social benefits minus costs to be maximised. The benefits include timber revenues and ground rent, recreation and wildlife use, regional development and employment, watershed use and conservation of forest resources. Social costs include both private sector costs and external costs such as regeneration, protection, roads, industrial costs, and any degradation of soil or water quality.

\section{b) The Forest Resources}

Alberta has 150,000 squares miles (388 $500 \mathrm{~km}^{2}$ ) of land classified as forest. Much of the forest land is not productive in commercial terms but there is nevertheless an enormous forest resource of potentially exploitable timber on 63,000 square miles (163170 $\mathrm{km}^{2}$ ) of the total forest area. The Alberta Forest Service (1968) estimated that the total volume of coniferous timber is 36 billion cubic feet (919 $\left.520000 \mathrm{~m}^{3}\right)$, with a potential annual allowable cut (A.A.C.) of 665 million cubic feet $\left(18832800 \mathrm{~m}^{3}\right)$. There is an estimated volume of deciduous timber of 24 billion cubic feet $\left(519680000 \mathrm{~m}^{3}\right.$ ) with an annual growth of approximately 665 million cubic feet (18 832800 $\mathrm{m}^{3}$ ). Planned rotations vary from 80 years to over 100 years.

Currently the actual harvest is less than onethird of the potential annual allowable cut. The forest represents an economic resource with considerable potential. Practically all of this resource is in Crown ownership. The Province expresses a policy of wishing to exploit the timber resource with particular emphasis on as complete utilisation of timber as is economically feasible. Timber is only part of the forest land resource and attention is given to soil and water conservation and wildlife values. Timber is of particular importance in terms of property rights since the private sector of industry has been permitted to develop timber harvesting, resulting in a divided tenure with shared rights in land; the Province retains ownership.

\section{c) The Historical Background}

The natural resources of Alberta were first placed into the ownership of the Provincial Government in 1930. The Department of Lands and Forests was created in 1949 at which time the Forest Act 1949 consolidated the disposal of all timber in Alberta under this one authority. The year 1957 saw the commencement of the first large scale pulp mill operations at Hinton under a lease of a sufficiently large area so that the mill was self sufficient in roundwood input. The Forests Act 1961 replaced existing legislation and "forests management lease agreements" were formalised. An amendment to the Forests Act 
1961 was made in 1965 which gave legislation authority for the Quota system of timber disposal. The Forests Act 1971 consolidated legislation and is the current act. In 1974, the Department of Lands and Forests became part of the Department of Energy and Natural Resources.

Timber disposal is carried out at present under three types of contracts, all of which are based on sustainable yields.

\section{i) The Forest Management Agreement. \\ ii) The Quota Agreement. \\ iii) The Timber Permit.}

\section{Forest Management Agreements}

\section{i) General}

The Forest Management Agreement (F.M.A.) is contracted for the specific company negotiating a lease on a specific area. The company has the right to enter the lease area for the purposes of managing, cutting and removing timber, and conducting incidental operations such as road and camp construction. Harvesting is associated with the building of a specific mill facility. The company does not have exclusive rights to enter and is only the "occupier" for certain purposes in connection with surface rights. The general public may use the land for recreational purposes within the limits of safety. The value of the contract is not diminished by a significant amount to the company, but the benefits of retaining rights to permit access to others is of considerable value to the Province.

The right to permit access for geographical exploration is also retained by the Province. The work of exploration may involve a reduction in value of the timber resource, however, since reasonable compensation has to be paid to the forestry firm this does not diminish the value of the contract to the firm. This does reduce the risk to the Province of having undervalued the forest land at the time of negotiation. Where surface works may be required in the event of a discovery of oil, gas, or mineral, the necessary area may be removed from the forest management agreement.

The right to manage the forest is governed by a set of ground rules. The company must regenerate cut over lands in a certain way and must act so as to conserve soil and water. The value of the contract to the company is diminished insofar as the management rights exchanged are not the full set of rights. The rights retained by the Province represent liabilities to the company since the cost of not infringing on retained Provincial rights diminishes the contract value.

The value of the contract to the Province is the compensation received for rights which are exchanged. This compensation consists of both financial compensation in the form of stumpage dues and charges and external, or social, benefits. Holding charges are payable for each square mile of lease area, (usually three dollars per square mile). Forest protection charges are paid by the company also, and these vary from approximately thirteen to twenty dollars per square mile. The rates of holding and protection charges are revised periodically to take account of inflation.

The holding and protection charges are made to cover services such as fire protection which the Province provides. The protection charges do not represent a net benefit to the Province and the extra costs involved in providing services may equal the charges made. However, risks may be reduced and enforcement cost covered.

The stumpage dues received by the Province are usually somewhat less in F.M.A. areas than the General Rate of Crown Dues. This should indicate that the social benefits accruing to the Province compensate for the lower dues. The Province would appear to take the view that a large scale development provides the benefits of a) a faster rate of regional development and b) greater utilisation of timber.

Since part of the benefits of entering into contracts with private industry are to promote resource development, provide employment, and enlarge the Provincial economic base, then a more rapid rate of development will tend to be considered beneficial, ceteris paribus. There is an opportunity costs involved to the Province of prolonging the development period by offering the area to be developed as a number of small Quotas instead of one large F.M.A. This opportunity cost must be weighed against the reduction in dues which is an inducement for the company to develop a large scale mill.

A greater degree of utilisation of timber can be achieved by having a mill capable of using small size logs and waste products. For pulp mills, such as at Hinton and Grande Prairie, a large timber input is required and a large F.M.A. area is essential. Both mills use waste wood from saw mills to a considerable extent. A single large saw mill is not necessarily more efficient than a number of small saw mills. However, the utilisation of waste products from the saw mill, plus the utilisation of small logs which can be achieved with a closely associated fibre processing plant such as a chipboard or fikre-board plant, would all tend to improve utilisation. A single large mill based on an F.M.A. is perhaps closer to the ideal than mills based on Quotas, though there is no evidence that the scale of the F.M.A. is at an optimum level.

Transfer costs can also be important. The costs of carrying out a feasibility study, negotiations, legal fees and other costs involved in setting up the contract are an overhead cost, the impact of which on unit costs of production can be minimised by treating the operation as an integrated whole.

\section{ii) Withdrawals}

It is possible for the Province to withdraw land from the F.M.A. The purpose of withdrawal rights is to reduce the risk to the Province of having incorrectly assumed that forestry use of the land would provide a satisfactory return to the land 
resource. Such an incorrect assumption could be a result of undervaluing other resources, or underestimating the costs. Both of these situations are covered in the F.M.A. since withdrawals can be made in the event that either

- any land is required for resource development

- any land cannot be logged without damaging ground water or surface water.

The company must be compensated in the event of a withdrawal. The rights retained by the Province cannot extinguish the capital value of timber which the company anticipated in entering the contract. However, the compensation offered contingent upon such withdrawals is patently incomplete, and the value of the contract to the company will be somewhat diminished as a result. Thus the negotiator for the company will offer less to the Province at the time of setting up the contract. This exchange point is considered suitable by the Province in view of the possible opportunity cost of committing land irreversibly for forestry use.

The reasons that compensation for withdrawals may be incomplete are

a) a certain proportion (up to $2 \%$ ) of a F.M.A. area may be withdrawn without being replaced with an equivalent area of the nearest available public timber lands.

b) even when replacement does take place, the company may face increased costs (e.g. transport) without necessarily being compensated for a consequent reduction in profit.

Also certain quantities of timber can be cut in the F.M.A. area without compensation. This is essentially a timber reservation built into the property rights. It is not a large quantity; generally 0.5 to $1.0 \%$ of the approved annual allowable cut. This timber can be cut pursuant to a timber permit being issued for the purposes of local constructtion, and government public works.

These reservations and withdrawals are important to the Province in providing for the regional development. The company must necessarily assume that the Province will act in good faith since compensation for withdrawals is determined by the Minister of Energy and Natural Resources.

\section{iii) Regeneration}

A convenient generalisation may be made that a company would not necessarily consider regeneration to be an essential part of their operation because of a limited planning horizon, the low profitability or regeneration outlays and the fact that the contract duration is not necessarily to be for the full rotation period. However, the Province does not exchange timber depletion rights in the F.M.A. contract. Sustained yields are the policy of the Province, and often the policy of forest management companies. However, a greater capital value could be obtained by offering the resource to a company on the basis of depletion. The fact that this is not done implies that the capital evaluation, whether implicit or explicit, uses a guiding rate of interest lower than other industrial sectors and in addition, is based on the fact that ownership will be retained indefinitely by the Province.

The regulations under which the company operates define the manner in which regeneration of the forest may be carried out. The extent, and shape of felling coupes are defined, partly with a view to controlling regeneration.

The felling, predominately clear felling, is undertaken in two stages. The first stage, as for example in the Ground Rules for North Western Pulp and Power (1972), involves cutting "no more than approximately $50 \%$ of the area of merchantable timber". The second stage removes the residual merchantable volume after regeneration is assured. The stated purpose of this is to regulate runoff, limit erosion, reduce continuous slash and hence fire risk, and to control seed source. In addition, the creation of edge effects which benefit wildlife is often considered important. It is not established that a $50 \%$ cut is an optimum point. The value of the contract to the company is less than would be the case if rights to a more profitable felling system were exchanged. However, there is a lack of information concerning the technical facts of how to reduce soil erosion, maintain water quality and yet harvest timber economically. The Province exhibits a considerable degree of risk aversion. It appears to take the view that it is not worthwhile exchanging rights which exhibit even quite a small probability of reducing the present value of net social benefits derived from the resource in the long run.

The Province has to bear some enforcement costs for regeneration. The company actually has to carry out the regeneration survey, but this reduces the value of the contract to the company and hence the negotiated exchange point will be of less financial value to the Province. The regeneration survey has to be carried out in the seventh year following the first cut. Inadequate natural regeneration requires stocking by artificial regeneration by the tenth year after the first cut. This time period is somewhat arbitrary and some evidence has been presented by Crossley (1976) in one of the F.M.A. areas that natural regeneration may increase in density up to the eleventh year. It is possible that some unnecessary expenditure may thus be incurred.

A further reduction of risk, and also reduction of enforcement costs, is achieved by the simple instrument of the right of the Province to "require the company to alter any of the methods (of forest management, reforestation, and forest protection) described in the plans;" as given in the F.M.A. with Procter and Gamble (1969). The acceptance of this clause, some form of which appears in all F.M.A.'s, requires the assumption of a deal of goodwill. Given that goodwill is assumed to be in evidence, there is relatively little reduction of contract value due to the inclusion of the clause. The right to sanction forest management methods is perhaps more important in the event of a default of the company of its obligation under, for example, Orders in Council, 1974, to "follow sound forestry practices with a view to 
achieving and maintaining a perpetual sustained yield". This right of sanction is in fact a convenient instrument by which to carry out enforcement of an essentially ill-defined concept of "sound forestry practices", but which is understood by local managers to include operations which enhance multiple-use, sustained yield forestry.

The fact that the Province does not exchange the right to deplete timber resources is a result of the fact that future yields are evaluated at a different rate of time preference by the Province than the company. This is most parsimoniously explained by the observation that the planning horizon is longer for the Province than the company. Regeneration costs of fifty dollars per acre on a typically long Alberta rotation of say 90 years are unlikely to be recovered, at discount rates of greater than $2 \%$. From this it might be inferred that financial feasibility is not the only consideration which the Province takes into account in determining the contract exchange point with regard to depletion rights. Additional social benefits accruing to present and future generations of Albertans are implicitly used in the formulation of policy on which the F.M.A. contracts are based.

\section{iv) Soil and Water Conservation}

The Ground Rules and Timber Management Regulations govern harvesting methods and road building so as to reduce soil erosion and maintain water quality. The Province does not exchange the right to degrade soil and water quality although this could be a financially attractive right for the company to possess.

Liabilities could be loosely defined as undertakings which involve costs to the company. Some "liabilities" such as timber extraction costs are inevitably considered to apply to the company, other liabilities need not be incurred in order to receive financial benefits, such as re-seeding a temporary access road. External costs in this context may be exemplified by the situation in which a company owned land outright and acted so as to maximize its financial wealth by degrading soil quality. The reduction of soil values to society would be an "external" cost because property rights in soil quality would not be in the ownership of those who value the rights most highly, viz. society. In general, society should under such cırcumstances, internalise the external cost by retaining or negotiating for the property rights, or by ensuring that a pricing system reflected the true costs and benefits of soil quality.

Tenure in Alberta permits conservation rights which are given a higher capital value by society than they might be given by the private sector, to be retained by the Province. These retained rights are then constraints within which the company must operate, and naturally determine the exchange point of the contract.

Ground rules under which the company operates are devised by mutual agreement and essentially help to show the company which practices are likely to be accepted by the Province when reviewing the yearly operating plan which must be submitted. Examples of rules which are designed to conserve soil and water are: a) no site disturbance may occur within 3 chains of the high water mark of major water courses; b) trees must be felled away from water courses; c) no debris is permitted to enter or remain in a water course; d) no trees may be removed within 1.5 chains of a secondary water course in steep terrain; e) no machine may operate within one chain of the high water mark of a main water course; f) no roads may be built close to lakes with recreation or wildfowl potential; g) revegetation of bared surfaces following road construction or skidding must be carried out.

These examples show the sorts of measures required for conservation. The opportunity costs to the company as a result of following such management practices need not be of too great a magnitude. The probability of the maximum contingent liability being incurred is a risk which the firm will attempt to minimise by making sure that costly erosion control measures will not be required. This risk averting behaviour on behalf of the company will maximise the total value of property rights at the exchange point. Incentives which stimulate this sort of behaviour should therefore be written into the contract, thus reducing risks to both parties, and also minimising enforcement costs.

\section{v) Protection}

The incentive of the operator to protect the forest resource could be important in determining the actual degree of risk experienced. Some riskreducing management practices are laid down as specific rules, such as the $50 \%$ first cut which reduces the continguous area of slash. Other aspects of management are also important, such as the provision of fire suppression and standby crews, and forest inspection for pests.

The company is not liable for any fire damage to Crown timber in an F.M.A. area, as exemplified by the Alberta Aspen Board Agreement (1972). It does however, have to pay the cost of suppressing any forest fire caused by company operations. The Province provides fire suppression crews and undertakes to pay the cost of fighting fires which are not the result of company operations.

The net result of these arrangements is that the Province bears much of the risk of fire damage, and much of the cost of providing standby crews. The Crown has the superior interest in the timber until it is cut and this is the essential reason that the Province chooses to provide protection. A protection charge is paid by the company which is intended to cover part of the cost of protection. By retaining the superior interest in timber, the Province also retains the right to sanction management plans and exert its control over company operations. These controls and sanctions are designed to protect long-term forest resource values, or in other words to reduce to an acceptably low level the physical risks to timber stocks of reducing timber stocks and harming the capac- 
ity of the land to produce timber in the future. The physical risk of fire should be kept at some low level, the optimum point being determined by weighing the costs of suppression and observation against the probability of destruction of valuable timber.

\section{vi) Summary}

The rights exchanged in a F.M.A. have been described above. It appears that the Province acts in a rather conservation fashion, retaining rights which provide controls on company operations, and can withdraw land from the F.M.A. area if costs or land values were incorrectly estimated at the time of negotiation. The Province makes use of entrepreneurial and managerial skills of the company in order to receive returns for forest land and the company makes use of the timber resources in order to receive returns for the factors of production it provides. It may be assumed that the company acts so as to maximise financial wealth. The motivation of the Province does not appear to be maximising financial wealth by maximising land rents. Regional development is an important motive. The behaviour of the Province is best described as risk-averting although not in the sense that the private sector averts pecuniary risks. The opportunity cost inherent in the system of management imposed appear to receive relatively little weight against apparent physical risks. In other words, a high implicit value is placed on sustained timber yields, and conservation of all forest resources.

Opportunity costs are incurred as a result of the lack of information on technical production. For example, the $50 \%$ by area first cut is not proven to be of greatest technical or economic efficiency, yet certainly results in higher logging costs than a more complete first felling. The size of the Forest Management Agreement Area is not necessarily optimum from the point of view of obtaining the benefits of rapid economic growth and increased value added. However, decisions must be made in the fact of uncertainty and estimates of financial and social benefits used in evaluating alternatives. The Province appears content to trade-off industrial costs against conservation values, while the industry might be expected to feel for example that costly logging practices not proved to be vital to conservation are unnecessary.

\section{Timber Quota System}

\section{i) General}

The quota system of timber disposal was brought into effect in 1965 in order to overcome a number of problems with the then existing system of selling timber licences to the highest bidder. The quota holder only has a right to apply for timber licences on the area of the quota, and pays a pre-determined rate of Crown dues, as set out in the Timber Management Regulations (1973).

It was suggested by the Alberta Forest Service
(1973) that under the competitive bidding system, timber resources were tending to be overcut and depleted in areas which had developed access roads and mill facilities. Other forested areas were underdeveloped. There was little incentive for industry to move into a new area since the firm could not be sure that they would always be successful in bidding for timber licences.

While the Quota system was not the only way of dealing with these problems it does provide an essential stability of tenure in timber rights with a 20-year renewable duration of contract. The forested land in Alberta is divided into a number of management units. Each management unit is allocated an annual allowable cut, based on von Mantel's formula.

The forest management unit is divided into a number of Quotas and each Quota holder has a specific share in the annual allowable cut of the management unit. Any changes in forest productivity alter the total annual allowable cut for the management unit as a whole. The result is an incentive to improve productivity and establish early successful regeneration. The concept of sustained yield in this context is aptly expressed by the Alberta Forest Service (1973) (page 6).

"The sustained yield concept required the regulation of the amount of timber cut in each management unit to avoid over-cutting in accessible units while remote timber decays. It also requires the renewal or regeneration of forest growth on cut-over lands, adequate forest protection and a permanent land base. The alternative to sustained yield is a shifting pattern of forest utilisation, whereby accessible forests are heavily cut in a short time followed by a migration of industry to more remote area where the pattern is repeated."

The Quota holder has the right to be issued with timber licences in order to be able to cut his share of the annual allowable cut for the forest management. The value of this contract to the quota holder is obviously the present value of the net revenues which will be obtained when operating under the expected timber licences. The quota, like the F.M.A., has associated holding and protection charges. The basic system of making Quotas available is intended to be by competitive bidding. This could theoretically provide the province with the residual of land rent. The amount offered for a Quota should be bid up in a competitive market so that the total of Quota prices, plus all dues and charges would equal the full economic rent of forest land. The actual value of holding a Quota is determined by the precise forest management practices permitted under the Timber Management Regulations (T.M.R.), as it is in the Forest Management Agreement.

A number of Quotas were awarded to operators who had successfully bid for timber licences in the period immediately prior to the 1965 amendment to the Forests Act 1961, which created the Quota system. Direct sales are also possible. Thus not all of the quotas have been subject to competitive bidding nor indeed payment of any sort.

The appraised rate of Crown dues as published 
in the Alberta Gazette (1974) is based on scaled stumpage removed and is set by a scale of percentages of the mill net price of lumber, from $5 \%$ when the price is below $\$ 91$ per M.F.M.B., to $15 \%$ when the price is over $\$ 129$ per M.F.M.B. In addition reforestation must be carried out, or a reforestation charge paid to the Province to carry out the work.

Since the introduction of the Quota system there has been a definite increase in the area of forest land exploited for timber production in the more remote areas of Alberta. Stability of tenure of timber rights appears to have encouraged the development of mill facilities and infrastructure. It would also seem that areas formerly overcut are now being harvested on a sustained yield basis.

\section{ii) Comparison with Forest Management Agreements}

Forest management agreements are negotiated specifically by each company concerned. Unique provisions may be built into the F.M.A., such as a cost-sharing agreement for pollution control with Procter and Gamble at Grande Prairie. The Quota conditions also permit some variation in the appraisal system under the Timber Management Regulations (1973) section 87 so that the rate of dues may vary with "the average size of trees to be cut, the average per acre volume of timber to be cut, the production of unsound wood, and the distance of the timber to railway transportation."

A quota may be cancelled if the quota holder does not cut at least $40 \%$ of the authorized annual allowable cut (AAC) during the first five years of the 20-year period of the quota, or at least $60 \%$ of the AAC during any subsequent period. Limits are laid down as to the variation from the AAC which can be allowed without penalty. In the F.M.A., the approval of the management plan and the operating plan is a direct means of controlling the quantity of timber cut. Quota holders also have to submit an operating plan at the time of application for a timber licence. The operating plan may be subject to revisions which the Minister has power to enforce. If it is in the "public interest" as set out in the Forests Act, 1971, Sections 24, and 25 to cancel a quota, or change its area, the Province retains the right to do so with 30 days notice, and compensation will be paid to the Quota holder at a level which the Minister of Energy and Natural Resources "considers just."

On the whole, the safeguards and provisions of sanctions on company operations are just as rigid for quota areas as F.M.A.'s, and are imposed for similar reasons. The rights of a holder of an F.M.A. are rather similar to that of a Quota holder with a timber licence issued. The charges and dues are paid on a similar basis for both types of contracts.

The annual allowable cut for the company is more directly affected in the F.M.A. The "allowable cut effect" may therefore be a logical part of management decision making. This effect is not so clear-cut for quotas due to a sharing of the AAC between quota holders.

\section{Timber Permits}

A commercial timber permit is quite different from the other forms of tenure since a specific area of land is harvested within a specific period of time. The timber permit will generally be issued subject to a number of conditions regarding harvesting operations. The holder of a timber permit must pay Crown dues and either reforest the area cut or pay a reforestation levy.

Timber permits may be purchased by competitive bidding on the rate of dues to be paid. Alternatively a timber permit may be offered to Quota holders in the area or failing their acceptance, to any person.

Local timber permits are issued for a period of one year only unless otherwise specified, and for volumes of less than 360,000 F.B.M. The holder of the permit is required to pay the crown dues on timber cut.

Obviously these timber permits provide a useful source of timber to those not managing Quotas and allow the province to deal effectively with timber outside of Quotas or F.M.A.'s.

\section{Charges and Stumpage Dues}

The holding and protection charges vary from 3 cents per acre on F.M.A. areas to 10 cents per acre on timber permit areas. The lower figure for the F.M.A. recognizes the fact that the forest will be retained in the tenure of the company concerned for a long period, whereas the timber permit holder will only pay for a limited period. A Quota holder has to pay holding and protection charges of 49 cents per thousand board feet of authorized annual allowable cut. This equates to a charge on a per acre basis of between $5 \phi$ to $10 \phi$ depending upon the productivity of the forest. All these charges are adjusted annually or periodically for inflation. They represent fixed charges in constant dollar terms. Thus behaviour of the firm in response to a change in charges is to examine overall profitability of the forestry enterprise but not necessarily attempt to change output. Neither the degree of utilization nor the introduction of intensive forest management practices would be affected by increasing the fixed charge.

The stumpage dues are a small proportion of gross revenue, perhaps as low as $2 \%$. Market risks are shared by the Province and the company. Since the dues are price-index linked in a sliding scale, the proportion of revenue from forest products which the Province receives will escalate as prices rise. This leaves the forestry company with a fair share of the profit, and provides the Province with an increasing return to the land. In the event of a sudden drop in the market price, Provincial revenues decline, while company profits decline less sharply than would be the case given a constant rate of dues. This reduces speculation on the timber market since there is a reduced incentive for the company to increase output at times of high prices. Whilst "speculation", or higher elasticity of supply, would tend to maximize rev- 
enues, it is in fact a statement of policy that the system of production control in contracts is designed to "prevent speculation". The Alberta Forest Service (1973) considers that the averagingout of the A.A.C. to a 5-year periodic cut permits some "speculation" or "legitimate" response to market fluctuations. The negative impact of even relatively short term variations in yield on the longterm productivity of the forest is given a heavy weighting in the trade-off between sustained yield and increased current revenues.

During the recent sharp decline in demand for lumber, the three-month moving average made adjustments too slowly so that a faster rate of decline of the rate of dues was required in order to maintain profitability. When the point was reached at which lumber prices gave returns to land on Quota areas which were zero or negative, the revised low level of dues was no incentive to remain in production. In fact, the clause requiring cancellation of Quotas for failing to cut a sufficiently high proportion of the authorized cut had to be suspended by amendment, since so many Quota holders were in this unfortunate position.

The F.M.A. and the Quota are rather similar in the mechanisms by which Provincial revenues are collected. One outstanding difference is the importance of the individual companies' management on its own authorized A.A.C., which is to say the allowable cut effect is somewhat "diluted" in Quotas. In addition, the scale of the agreement permits more fully integrated operations to be carried out in the F.M.A. which would perhaps tend to give better utilization.

\section{Summary}

\section{i) General}

A sustained yield of timber is achieved by providing private sector companies with stability of tenure and assured rights in timber. The use of private entrepreneurial and managerial ability, and equity capital is considered to be the most efficient means of achieving the goals of regional development which are associated with ensuring sustained yields throughout Alberta rather than just concentration on areas with the advantage of location given the existing infrastructure.

Sustinance of other forest land resources is achieved by detailed planning of private sector forest management techniques and retaining the right to demand revisions to the plans. Penalties may be imposed to enforce the use of correct, "sound" forestry practices.

The Forest Management Agreement provides an opportunity to develop large scale integrated mill facilities, and the Quota System permits both yield control and development by providing stable tenure and a system of reflecting the economic disadvantages of location and timber characteristics in the appraisal system for dues. Both systems, one for unique cases, and one for the more general case, provide an opportunity for selective development of forest resource so as to achieve a Province-wide sustained yield.

\section{ii) Specification of Liabilities}

The company extracts timber, builds and maintain roads, constructs the mill, and carries out forest management practices often including regeneration. The Province provides fire protection. It also shares in the nursery work since there are considerable advantages to scale in having a large Provincially-operated nursery. The objective of specifying liabilities is to provide an incentive for the operator to minimise costs.

\section{iii) Sharing Risks}

The risk of catastrophic loss due to fire is mainly borne by the Province but the company could lose through the reduction in the timber resource base.

Market risks are shared, but tend not to be minimised due to the implementation of sustained yield policy which creates a relatively inelastic supply response to price fluctuations.

\section{iv) The Exchange Unit}

The unit of exchange is basically volume of wood, but the rights of holders of F.M.A.'s and Quotas are to some extent related to area of land.

The two part pricing system is meant to ensure an adequate return to land given that uncertainties exist with regard to market prices for the product and there is no free market in forest land.

\section{v) Enforcement Costs}

Enforcement costs through checking of records and performance is an inevitable part of the system. Given the powers of the Province to cancel contracts in the event of a failure to comply with the measures of the Forests Act, the risks to the company are maximised and hence enforcement cost minimised.

\section{vi) Duration}

The 20-year renewable period of duration of contracts provides sufficient and satisfactory stability of tenure for most companies.

\section{References}

Alberta Forest Service. 1968. Alberta Forest Inventory.

Alberta Forest Service. 1972. Consolidated Ground Rules North Western Pulp and Power Ltd. Forest Management Area.

Alberta Forest Service. 1973. The Quota System of Timber Disposal Edmonton 1973.

Alberta Gazette, May 15th. 1974.

Crossley, D. I. 1976. "The ingress of regeneration following harvest and scarification of lodgepole pine stands". For. Chron. 52(1) Feb.

Forests Act, The. 1971. Sect. 24; Sect. 25.

Orders in Council under The Forests Act, 1971. 1974. Forest Management Agreement with the Procter and Gamble Company of Canada Limited Sec. 12(3) O.C. 1/69.

Orders in Council under The Forests Act, 1971. 1972. Memorandum of Agreement O.C. 365/74 Sect 8(a).

Sec. 20 para 3.

Orders in Council under The Forests Act, 1961. 1969. Memorandum of Agreement O.C. 365/74 Sect 8(a).

Timber Management Regulations. 1973. Alberta Regulation $60 / 73$. 